\title{
Erratum: Responses to migration: Tensions and ambiguities of churches in Pretoria Central and Mamelodi East
}

\begin{tabular}{|c|c|}
\hline \multicolumn{2}{|c|}{$\begin{array}{l}\text { Author: } \\
\text { Wayne Renkin }{ }^{1,2,3} \text { (D) }\end{array}$} \\
\hline \multicolumn{2}{|c|}{$\begin{array}{l}\text { Affiliations: } \\
{ }^{1} \text { Centre for Contextual } \\
\text { Ministry, Faculty of Theology, } \\
\text { University of Pretoria, South } \\
\text { Africa }\end{array}$} \\
\hline \multicolumn{2}{|c|}{$\begin{array}{l}{ }^{2} \text { Department of Practical } \\
\text { Theology, Faculty of } \\
\text { Theology, University of } \\
\text { Pretoria, South Africa }\end{array}$} \\
\hline \multicolumn{2}{|c|}{$\begin{array}{l}{ }^{3} \text { Tshwane Leadership } \\
\text { Foundation, South Africa }\end{array}$} \\
\hline \multicolumn{2}{|c|}{$\begin{array}{l}\text { Research Project Registration: } \\
\text { Project Leader: S.F. de Beer(D) } \\
\text { Project Number: } 86233689\end{array}$} \\
\hline \multicolumn{2}{|c|}{$\begin{array}{l}\text { Description: } \\
\text { This research is part of th } \\
\text { research project, 'Social } \\
\text { Justice and Reconciliation } \\
\text { which is directed by Dr } \\
\text { Stephan de Beer, Directo } \\
\text { the Centre for Contextua } \\
\text { Ministry and member of } \\
\text { Department of Practical } \\
\text { Theology, Faculty of } \\
\text { Theology, University of } \\
\text { Pretoria. }\end{array}$} \\
\hline \multicolumn{2}{|c|}{$\begin{array}{l}\text { Corresponding author: } \\
\text { Wayne Renkin, } \\
\text { wayne@tlf.org.za }\end{array}$} \\
\hline \multicolumn{2}{|c|}{$\begin{array}{l}\text { Dates: } \\
\text { Published: } 22 \text { Dec. } 2017\end{array}$} \\
\hline \multicolumn{2}{|c|}{$\begin{array}{l}\text { How to cite this article: } \\
\text { Renkin, W., 2017, 'Erratum: } \\
\text { Responses to migration: } \\
\text { Tensions and ambiguities of } \\
\text { churches in Pretoria Central } \\
\text { and Mamelodi East', HTS } \\
\text { Teologiese Studies/ } \\
\text { Theological Studies 73(3), } \\
\text { a4901. https://doi. } \\
\text { org/10.4102/hts.v73i3.4901 }\end{array}$} \\
\hline \multicolumn{2}{|l|}{ Read online: } \\
\hline 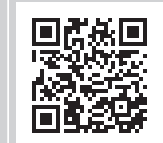 & $\begin{array}{l}\text { Scan this QR } \\
\text { code with your } \\
\text { smart phone or } \\
\text { mobile device } \\
\text { to read online. }\end{array}$ \\
\hline
\end{tabular}

In the version of this article initially published, the incorrect funding information was acknowledged in the note. The note is hereby corrected and updated as: 'This article forms part of a collaborative research project entitled "Religious innovation and competition amidst urban social change: A Pretoria case study." The project was funded by the Templeton Foundation as part of an African-wide enquiry on "Christianity and social change in contemporary Africa." The project is also a sub-theme of the "Faith in the City" research project, hosted by the Centre for Contextual Ministry in the Faculty of Theology, University of Pretoria'. This correction does not alter the study's findings of significance or the overall interpretation of the study results. The editor apologises for any inconvenience caused. 


\section{Responses to migration: Tensions and ambiguities of churches in Pretoria Central and Mamelodi East}

\begin{tabular}{|c|c|}
\hline $\begin{array}{l}\text { Author: } \\
\text { Wayne Renkin }\end{array}$ & 2,3 (1) \\
\hline $\begin{array}{l}\text { Affiliations: } \\
{ }^{1} \text { Centre for Co } \\
\text { Ministry, Facu } \\
\text { University of P } \\
\text { South Africa }\end{array}$ & $\begin{array}{l}\text { ntextual } \\
\text { ty of Theology, } \\
\text { retoria, }\end{array}$ \\
\hline $\begin{array}{l}{ }^{2} \text { Department } \\
\text { Theology, Facu } \\
\text { Theology, Uni } \\
\text { Pretoria, Sout }\end{array}$ & $\begin{array}{l}\text { f Practical } \\
\text { Ity of } \\
\text { ersity of } \\
\text { Africa }\end{array}$ \\
\hline $\begin{array}{l}{ }^{3} \text { Tshwane Leac } \\
\text { Foundation, S }\end{array}$ & $\begin{array}{l}\text { lership } \\
\text { uth Africa }\end{array}$ \\
\hline $\begin{array}{l}\text { Research Proj } \\
\text { Project Leade } \\
\text { Project Numb }\end{array}$ & $\begin{array}{l}\text { ect Registration: } \\
\text { : S.F. de Beer (D) } \\
\text { er: } 86233689\end{array}$ \\
\hline $\begin{array}{l}\text { Description: } \\
\text { This research } \\
\text { research proje } \\
\text { Justice and Re } \\
\text { which is direct } \\
\text { Stephan de Be } \\
\text { the Centre for } \\
\text { Ministry and n } \\
\text { Department o } \\
\text { Theology, FacL } \\
\text { Theology, Uni } \\
\text { Pretoria. }\end{array}$ & $\begin{array}{l}\text { s part of the } \\
\text { ct, 'Social } \\
\text { conciliation', } \\
\text { ed by Dr } \\
\text { er, Director of } \\
\text { Contextual } \\
\text { nember of the } \\
\text { f Practical } \\
\text { lty of } \\
\text { ersity of }\end{array}$ \\
\hline $\begin{array}{l}\text { Correspondin } \\
\text { Wayne Renkin } \\
\text { wayne@tlf.org }\end{array}$ & $\begin{array}{l}\text { author: } \\
\text { za }\end{array}$ \\
\hline $\begin{array}{l}\text { Dates: } \\
\text { Received: } 30 \mathrm{~J} \\
\text { Accepted: } 13 \\
\text { Published: } 29\end{array}$ & $\begin{array}{l}\text { une } 2017 \\
\text { Aug. } 2017 \\
\text { Sept. } 2017\end{array}$ \\
\hline $\begin{array}{l}\text { How to cite th } \\
\text { Renkin, W., } 20 \\
\text { to migration: } \\
\text { ambiguities of } \\
\text { Pretoria Centr } \\
\text { Mamelodi Eas } \\
\text { Teologiese Stu } \\
\text { Theological St } \\
\text { a4725. https:/ } \\
\text { org/10.4102/ }\end{array}$ & $\begin{array}{l}\text { is article: } \\
\text { 17, 'Responses } \\
\text { ensions and } \\
\text { churches in } \\
\text { al and } \\
\text { ', HTS } \\
\text { dies/ } \\
\text { Idies 73(3), } \\
\text { doi. } \\
\text { ts.v73i3.4725 }\end{array}$ \\
\hline Read online: & \\
\hline 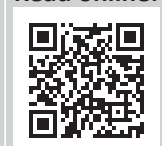 & $\begin{array}{l}\text { Scan this QR } \\
\text { code with your } \\
\text { smart phone or } \\
\text { mobile device } \\
\text { to read online. }\end{array}$ \\
\hline
\end{tabular}

This article is a result of research being conducted to explore how churches in two regions of the City of Tshwane - Pretoria Central and Mamelodi East - respond to urban change and vulnerability. Both regions are deeply affected by urban migration patterns. Firstly, I will explore various forms of migration - transnational, rural-urban, urban-suburban and generational - and the causes of migration - social-economic and political - as experienced and described by the churches themselves. Secondly, I will seek to reflect on some of the tensions or ambiguities of how churches respond to migration, how the identity, self-understanding or locatedness of churches inform their responses to migration, and/or how churches and their identity are shaped by migration - commuter or local church, home or temporary church.

\section{Introduction}

With the rapid urbanisation, the development of technology and the increasingly affordable and accessible transportation, migration becomes more and more part of our societies and cities. Migration has always been part of humanity, but not at the magnitude we find today. As migration continues to be on the rise, it dominates public debate, popular media and academia. In his book Arrival Cities, Doug Saunders (2010) writes that the 21stcentury will be remembered for the greatest human population shift, that is, migration to urban areas. Saunders compares the current migration with the migration between the 18th and 20th centuries when people migrated to and from Europe and the so-called new world.

Today, more than $60 \%$ of the South African population live in urban areas. In theory, people have of freedom of movement, but this is juxtaposed by the legacies of the apartheid system in terms of spatial justice and economic disparities (Reed 2013:2, 3; Statistics South Africa 2010).

Migration and the presence of migrants tend to be presented as problematic and negative by the popular media, academia and in political debates. De Haan (2000) notes that it is:

often seen as the consequence of ruptures, of environmental disaster, economic exploitation, or political or civil tensions and violence. And it is often perceived to be a cause of problems, like environmental degradation, health problems, 'brain drain', political or social instability, declining law and order, and unravelling social fabric and support systems. (p. 1)

Bakewell $(2008: 19,20)$ affirms De Haan's observation that migration is seen as negative and also notes the 'negative rhetoric of "mainstream" international' non-governmental organisations (NGOs). Reference to migration by international NGOs is 'almost invariably cast it as the cause or symptom of multiple problems in developing regions, especially Africa'.

Not only the media, academia, political debates or NGOs but also society views migration as negative. This view clearly manifests in marches such as the anti-immigrant march in Pretoria (Chabalala 2017; News24 Reporters 2017). Bakewell $(2008: 35,36)$ states that migration and mobility are assumed as normal for the wealthy, international elite, but for poor communities, they are seen as a symptom of failure.

'[M]igration and urbanisation are processes that offer hope for the future', but this is not always understood or appreciated (Kok \& Collinson 2006:1). Although Kok and Collision may hold that that migration and urbanisation are processes that offer hope for the future, there is an underlying 'resentment of those who have succeeded, and antipathy to newcomers, especially foreign migrants'

Note: The collection entitled 'Spirit rising: tracing movements of justice', forms part of the 'Faith in the City' research project, hosted by the Centre for Contextual Ministry in the Faculty of Theology, University of Pretoria. Some of the articles were papers presented at the Biennial Consultation on Urban Ministry, hosted by the Institute for Urban Ministry, in collaboration with other organizations, from 17-20 August 2016. The theme of this Consultation was “\#We must rise: healers - dreamers - jesters.

Copyright: @ 2017. The Authors. Licensee: AOSIS. This work is licensed under the Creative Commons Attribution License. 
(Gauteng City-Region Observatory n.d.). The United Nations' Department of Economic and Social Affairs (2016) reports that migrants are vulnerable in their host societies:

migrants are prone to vulnerability in society as they are often the first to lose their job in the event of an economic downturn, often working for less pay, for longer hours, and in worse conditions than national workers. (p. 2)

It is not an easy task for migrants to integrate in a host country of city, but social networks are ways in which migrants 'circumvent structural disadvantages in the host society' (Levitt \& Jaworsky 2007:135). Social networks help communities build social capital and facilitate integration:

Cross-border ties imbue ethnic communities with valuable social capital that can foster their horizontal and vertical integration. These effects extend far beyond the economic-the right type of social capital can help ethnic communities cut across class and spatial boundaries and barriers and help facilitate mobility for the second generation.(p. 135)

In the United States, Morris (1996:30) notes that the urban black church experienced tremendous growth between 1910 and 1960. The process of urbanisation for black communities did not come without its problems and issues. The church played a critical role in addressing the problems and issues as well as facilitating the integration for the rural-urban migrants by 'offering valuable friendships and social networks through which the migrants could assimilate into urban life' (Morris 1996:30).

To get a better understanding of migration, we need to understand migration patterns and statistics. Various institutions track and collects statics about migration, but it is important to note that 'migration data is fragmentary, fluid and often imprecise' (Adepoju 2016). The census data often do not include specific migration questions (Bakewell 2008:14). It is further complicated by the fact that migration in Africa over land borders as often crossed with minimum formalities (Bakewell 2008:14). According to the United Nations' report, International Migration Report (2016), international migration has grown from 173 million in 2000 to 244 million in 2015 worldwide. The World Bank (2016) reports a figure that is a bit higher that in 2013247 million people live outside their countries of birth.

Twenty-one million of 244 million reported international migrations live in Africa and 34 million of the international migrations are born in Africa. It is reported that in 2014 there was an estimate of 19 million refugees only worldwide. Almost 6.0\% (3 142 500) of the South African population are migrants as reported by the United Nations $(2016: 7,15,29)$.

It is necessary to reflect on migration theologically. Throughout the bible, there are stories about migration to known and unknown places. In Genesis 12, God called Abraham to leave his current home and move to an unknown place. The children of Jacob migrated to Egypt in a time of famine. The Israelites migrated from Egypt out of slavery to a new land. The Israelites are constantly reminded in the book of Deuteronomy that they were migrated to a foreign land and were aliens in that land and therefore, they must not oppress aliens that live among them (Groody 2013:29).

In his book The Christian Imagination: Theology and the Origins of Race, Willie James Jennings (2010) traces how European Christians understood that God called them to go to the rest of the world to create civilisations through the spreading of the Gospel. They migrated and 'discovered' new worlds, bringing their world with them. The migration Jennings describes is one of domination, of colonisation. The migrants from Europe occupied the so-called new world.

From Abraham all the way right through the bible, the early church, the spreading of the Gospel worldwide, and the crusades, it is clear that at the core of Christianity is migration (Groody 2013; Terreblanche 2014). Authors such as Groody (2013) and Wright (2010) describes the migration of 'God's people' in a more positive light than authors such as Jennings.

Whether the migrations that were inspired by a Christian faith were positive or negative, it is clear that religion and migration is closely linked. Peggy Levitt (2003:848) suggests that because of the close link between religion and migration and that they use 'religious institutions to live their transnational lives', they have multiple identities, having close links to where they come from and to where they find themselves.

After a shipwreck that claimed many lives of refugees at the island of Lampeduse in 2013, Pope Francis went to the island. In a homily on the island, the Pope reminded us of our interconnectedness. He further points outs that humanity has 'lost a sense of empathy toward others in pain' and that we have also lost 'a sense of our interconnection with each other'. The Pope went to island to:

'offer a sign of my closeness ... to challenge our consciences' and to pray for the thousands who have lost their lives migrating from countries like Eritrea, Somalia, Afghanistan, Egypt, Gambia, Mali, Pakistan, and Syria. (Groody 2015:316-317)

This article is part of a research project entitled 'Religious innovation and competition amidst urban social change: A Pretoria case study'. The project focused on two regions in the City of Tshwane Metropolitan Municipality, Pretoria Central and Mamelodi East. Pretoria is the administrative capital of South Africa and it carries many legacies of apartheid: poverty, inequality, spatial injustices, racial and economic disparities. It is seat of political power in South Africa. Pretoria Central experienced extreme demographic change during the early 1990s, as the apartheid laws only allowed white people to live in the cities. The city witnessed a changed from being a white only city to being a majority black city. Majority of white people moved from the inner city to the suburbs. Pretoria Central is also a catch basin to internal migration as well as external migrants from other African countries. Mamelodi is the largest Township in the City of Tshwane. It has faced many challenges such as lack of resources for development and forced removals over many years. There is a strong migration link between Pretoria 
Central and Mamelodi as people commute on a daily basis between the two areas. They move between the two areas either for economic or social reasons.

Both of the areas experience migration in various forms: rural-urban, urban-suburban, transnational, generational and circular migration. The research project is interested in understanding how churches in these two areas experience and describe migration and how the migration shapes their identity as church.

\section{Urban migration in South Africa}

South Africa lacks historical comprehensive and detailed data on migration. Before the 1996 census, research and 'migration analysts relied on sample surveys that are neither detailed nor comprehensive enough for an understanding of this dynamic phenomenon' (Kok et al. 2003:1). Furthermore, the data that was gathered on migration did not focus on the entire population of South Africa. It excluded 'nominally independent states of Transkei, Venda and Bophuthatshwane' (Kok et al. 2003:1). The apartheid government also censored 'data about the black population', and the 'existing knowledge about historical patterns of black migration within South Africa is incomplete at best' (Reed 2013:1, 2). Therefore, we cannot try and understand the history of migration in South Africa without acknowledging the role of apartheid and how the apartheid city legacies are still evident today (cf. Swilling, Humphries \& Shubane 1991). The apartheid system systematically excluded black Africans and through 'racial, political, economic and theological views' only 'saw the movement of black Africans only as the means of cheap and docile labour' (Vellem 2014:2).

In the 1940s, South Africa experienced a migration of Afrikaners of such significance, that the Dutch Reformed Churches appointed a special commission of inquiry to 'study the church and the religious situation in the nine major cities of the then Union of the South Africa' (Vosloo 1947:21,

24). The goal of this inquiry was:

to gather information on the economic, social and religious situation of the members of the Dutch Reformed Churches in the cities of the Union of South Africa, and to interpret these data to indicate the church's course of action for the future. (p. 24)

The inquiry excluded black African people, except where it has an impact on white people, and only focused on urban white areas:

The inquiry was furthermore limited to urban whites, although the report states the need for reflection on the situation of black people in the cities and the significance of this for the church. However, the report referred to black urbanisation only as it impacted on white urbanisation, for instance, when dealing the mixing of races and segregated neighbourhoods. (Vosloo 1947:24)

During the apartheid years, black African people were only referred to in relation to white people. The inquiry by the Dutch Reformed Church echoes this notion. This was not only evident in social understanding, but the Native Act of 1923 provided a way to create a systemic way of referring to black African people only in relation to white people. The act was an attempt to curb the urbanisation of black Africans into white apartheid cities. The pass laws that were instituted later only strengthened the systemic curbing of the urbanisation of black Africans. The Native Act of 1923 was based on a dictum of the 1921 Transvaal Government Commission, which was chaired by Colonel Frederick Stallard. The dictum stated:

The Native should only be allowed to enter urban areas, which are essentially the white man's creation, when he is willing to minister to the needs of the white man, and should depart therefore when he ceases to minister. (Terreblanche 2002:255; Vellem 2014:4)

Other attempts to curb black urbanisation and to reduce rural-urban migration included the development and investment in rural areas. This was not only done to address issues of poverty, but also to control migration and reduce the need for migration (Bakewell 2008:6-9). However, urbanisation throughout the African continent as well as the rest of the world has increased despite the various attempts to slow down or stop it (Bakewell 2008:10; Saunders 2010).

Oliver Bakewell notes that 'the functioning (and profitability) of the colonial state [apartheid South Africa] required that [African] people move to work,' but they should not settle. They were welcomed to sell their labour, but they 'should retain their link with their homelands and ideally, when they finished their contract or came to retirement, they would return "home" to make way for new labourers'. A strong emphasis on people to return where they came from was to ensure that the government knew where people were, which was also controlled by the pass laws of the apartheid South Africa.

\section{Statistics}

In this section, I will be presenting statistics that is important to understand the legacies of apartheid that perpetuate injustices today. Firstly, I will be presenting the statistics of the South African population and the recorded birth countries (within South Africa, the Southern African Development Communities or the rest of Africa).

Secondly, I will be presenting the statistics of the Gauteng region: the population, the percentage that are South African citizens, internal migration through the statistics of where people living in Gauteng are born in South Africa and other countries of birth. The types of dwellings and access to toilet will also be presented. The statistics about the types of dwellings and access to toilets are presented to show the disparities that still exist today and how the legacies of the apartheid city still shape how people live on a daily basis.

Thirdly, the statistics of the City of Tshwane Metropolitan Municipality will be presented. To get a better understanding of the migration in Tshwane, the population, citizenship, 
province of origin in South Africa and countries of birth will be presented. As Tshwane is the capital city and houses the seat of political power in South Africa, it is important to reflect on the types of dwellings and the access to toilets the population has.

Lastly, I will be presenting the statistics of Pretoria Central and Mamelodi, the two areas that the research project is focused on. The statistics about Pretoria Central includes the inner city and the outskirts of the city centre. Although the research only focuses on Mamelodi East, the statistics that will be presented is on the whole Mamelodi area.

According to the 2011 Census (Statistics South Africa 2011), South Africa had a population of 51770 561. It grew to 55653654 in 2016 (Statistics South Africa 2016). Of the population of South Africa, 92.9\% (48 083 729) are born in South Africa, with 2.4\% (1 219 891) born in the Southern African Development Community (SADC) region, 0.3\% (132 753) from the rest of Africa and the birth place of $4.2 \%$ (2 165 991) people is unspecified.

Gauteng's population grew from 12272263 in 2011 (Statistics South Africa 2011) to 13399724 in 2016 (Statistics South Africa 2016). Of the population of Gauteng, $88.0 \%$ are born in South Africa and $90.4 \%$ of the population are South African citizens (Statistics South Africa 2011).

There is greater internal migration into Gauteng from other provinces in South Africa than external migration. Of the population of Gauteng, 54.4\% were born in the Gauteng region. The other South African provinces of birth include (internal migration) Limpopo (10.5\%), KwaZulu-Natal (5.7\%), Eastern Cape (4.4\%) and Mpumalanga (4.2\%). Of the residents of the Gauteng population, 9.3\% are born outside South Africa (external migration), with $5.4 \%$ born in the SADC region, $0.5 \%$ in the rest of Africa and $11.6 \%$ are born in places specified as 'other'.

As urbanisation is on the rise and the Gauteng region is the economic hub and the political power in South Africa, information about the types of dwelling and the access to toilets is important to reflect on. This paints a picture not only of the legacies of apartheid, but also about how ready the Gauteng region is for the rapid urbanisation growth and the internal as well as external migration into the Gauteng region.

Fifty-nine percent of the Gauteng population live in houses, $18.9 \%$ in shacks, $7.2 \%$ in apartments, $5.6 \%$ in backyard flats and $9.3 \%$ live in dwellings described as 'other'. Of the population, $0.9 \%$ have no access to toilets. This is about onefifth of the rate of South Africa, but it remains alarming that there are 114322 people with no access to any form of toilets. Of the population, $86.3 \%$ have access to flush toilets, $9 \%$ pit toilets, $1.4 \%$ chemical toilets and $2.4 \%$ have only access to toilets described as 'other'.

The City of Tshwane is the capital city of South Africa, and houses the seat of political power. It is home to 2921488 people (Statistics South Africa 2011). Of the population, 89.9\% are born in South Africa and $91.8 \%$ have South African citizenship. Of the population of the City of Tshwane, 53.3\% were born in Gauteng, $14.6 \%$ in Limpopo, $6.6 \%$ in Mpumalanga, 5.6\% in North West, 2.5\% in KwaZulu-Natal, $10.7 \%$ in places described as 'other'. Of the population, $6.7 \%$ are born outside South Africa (external migration), with 3.7\% born in the SADC region and $0.5 \%$ born in the rest of Africa.

A total of $61.2 \%$ of the household dwellings in the City of Tshwane are houses, $18.0 \%$ are shacks, $8.2 \%$ are apartments, $4.8 \%$ townhouses and $7.8 \%$ are classified as 'other'. Of the population, $1.1 \%$ have no access to toilets, $79.1 \%$ have access to flushing or chemical toilets, $17.5 \%$ have access to pit toilets, $0.8 \%$ have bucket toilets and $2.2 \%$ have access to toilets classified as 'other'.

The Pretoria central region has a total population of 741651 . Of the dwellings in Pretoria Central, $97.2 \%$ are considered formal dwellings. Considering that this is the city region of the City of Tshwane, it is alarming that $0.5 \%$ of the people do not have access to any form of toilet facility. Of the population, $98.0 \%$ have access to flush or chemical toilets, $0.5 \%$ have only access to bucket toilets, $0.8 \%$ have access to pit toilets and $0.3 \%$ only have access to toilets described as 'other'. Although $0.5 \%$ is not a large number, but this is still significant in a place such as Pretoria that is a city that houses the political power in South Africa.

The Mamelodi region has a population of 334577 (Statistics South Africa 2011). There are sources that estimate that this is a conservative figure and that the population is closer to 1 million (See Van Eck, Renkin \& Ntakirutimana 2016:4). 61\% of the dwellings are classified as formal. People in Mamelodi having access to flushing or chemical toilets $(71.8 \%)$ are less that Pretoria Central. $24.5 \%$ of people have only access to pit toilets, $0.9 \%$ to a bucket toilet and $1.3 \%$ people have only access to toilets that are described as 'other'.

\section{Forms of migration as described by the churches}

The urbanisation process, the exploration of migration in South Africa and the statistics are important as they give contexts to the two areas that the research is focused on.

The research project used three different forms of gathering information. De Beer (2017) describes the methodology of the research study, but I want to highly a few aspects of the information gathering process.

Firstly, the researchers, with the assistance of a geoinformatics professional, mapped the churches in the two regions. It was assumed that mapping the churches would be a much easier task as it turned out to be.

Majority of the churches in the Pretoria Central region are hosted in formal buildings, with banners or advertising boards announcing their presence. There are churches that 
make use of less formal spaces or open spaces, and they are only present on the day of worshipping. During the mapping process, it was discovered that most of the churches in the inner city are clustered together, mostly right next to each other in single story buildings. They are located in spaces that would either commonly be used for store-fronts or warehouse purposes. They form almost 'religious shopping centres', where people can go from one church to the next, without much effort. The mainline churches (such as the Catholic Church, Anglican Church, Methodist Church, Uniting Reformed Church of Southern Africa, Nederdutch Reformed Church, and United Presbyterian Church) are located in buildings that are typically considered 'church buildings', and are more spread throughout the city.

The mapping process in Mamelodi was a much more challenging task that in Pretoria Central. The majority of the churches in Mamelodi do not make use of formal buildings, and they do not always have banners and advertising boards that announce their presence. Although their presence is not announced in a 'marketing' manner, their presence is known by the neighbourhood. The presence of the churches is clear on a Sunday: there are tents, communities worshipping and people who gather in open spaces. It was discovered that many churches in Mamelodi use tents or open spaces as places of gatherings. School buildings are also used as places where churches gather. Almost all the schools in the specific area of the research host more than one church at the same time.

The second research method to gather information was to make use of survey forms. The survey forms contained questions regarding the demographics (male, female, languages, nationalities, etc.) about the congregants, leadership styles, church finances, challenges, worshipping, how churches respond to various vulnerabilities and competition with other churches. The survey forms were given to the churches that were identified during the mapping process.

The survey forms revealed that in the Mamelodi churches, the majority of the congregants are South African and the languages spoken in the churches are one of the 11 official languages of South Africa. In Pretoria Central, the survey revealed a different picture. The communication language of the majority of churches is either described as diverse or English. The nationalities of the congregants are not only South African but included people from other African countries.

The third method of gathering information was to have focus groups with a few churches. In the next part of the article, I will be exploring what the focus groups surfaced in terms of (or the lack of) migration and how churches articulated how they see, understand and respond to migration.

The churches in Mamelodi did not surface migration as a theme in the focus groups nor during the world cafe sessions. The only migration they mentioned is people that are not living close-by, travel to the church on a weekly basis. The churches that took part in the focus groups in Pretoria Central represent mainline churches, Independent churches, Reformed churches, Pentecostal churches, and Charismatic churches. They are also spread throughout Pretoria Central, representing different neighbourhoods.

During the focus groups, different forms of migration were surfaced: transnational, rural-urban, urban-suburban, and generational migration. The migrations were either described as permanent, temporary, or goal-orientated.

Majority of the forms of migration that were surfaced were either rural-urban migration or transnational migration. The responses and reflections about rural-urban and transnational migration differed.

The churches surfaced that there is a strong presence of people within their churches and communities who fall within the category of rural-urban migrants. The majority of the people who fall within this category are seeking employment in the city. It was clear in the focus groups that they perceived the presence of economic migrants negatively. They assumed that it contributes to the rising unemployment rate, poverty and the decline of safety in the area.

The idea that rural-urban migration causes unemployment and poverty is a 'commonly held misconception'. Kok and Collinson (2006:2) suggest that migration of unemployed people is merely the displacement of unemployment:

Rural-urban migration can only cause unemployment if employed rural persons migrate to urban areas and stay there while remaining unemployed. [...] The fact that migration and urbanisation can lead to a displacement of unemployment should therefore not be confused with a notion that these processes are the causes of unemployment. With temporary labour migration this negative association with unemployment is unlikely because migration can be seen as a job-hunting strategy, which is the means of lessening unemployment in the rural population; formerly this was coerced through the labour migrant system but presently it is the most promising job-hunting strategy for young people in rural areas. (p. 2)

It is, therefore, highly unlikely for people to contribute to the overall unemployment rate if it is only the displacement of unemployment, but they may be contributing to the unemployment rate in the immediate community.

Economic migration is not the only reason for rural-urban migration. As mentioned, the churches perceive the presence of economic migrants as negative, but they were more sympathetic towards women who migrated to escape situations of abuse. Although they are more sympathetic, the churches attempt to return the women to their places of origin without addressing the systematic issues that the women are trying to escape.

Another cause of rural-urban migration is educational migrants, that is, people migrating to urban areas for educational purposes; either seeking higher education, 
furthering education or gaining access to education. There exists a perception that there are better education opportunities in the city (Gauteng City-Region Observatory n.d.). The reflections and perceptions about educational migrants were overall more positive than economic migrants. The churches mentioned that the youth who are educational migrants, may have negative experiences in the city. They firstly have a lot of pressure from home or their families to excel and succeed so that they can in return and contribute financially to the family. Another pressure the youth face is that they are much more exposed to alcohol and drugs in the city. A focus group mentioned a few examples of youth who came to the city in seeking education but ended up on the streets. Another concern that was raised that the youth do not have a church they can call 'home' in the city, but instead they seek churches where the pastors drive expensive cars and they can rub shoulders with celebrities and fall within the 'rat-race' trap.

'There is a widespread perception that better work and education opportunities are available' in Pretoria as well as 'general better standards of living' (Gauteng City-Region Observatory n.d.). This creates a pulling factor and increases rural-urban and transnational migration. The increase of migrants creates a more diverse society that has an increasing 'cosmopolitan character and vibrant social and economic life' (Gauteng City-Region Observatory n.d.). This in turns creates a less mono-culture church, a more accepting society and 'attractiveness to opportunity seekers' (Gauteng City-Region Observatory n.d.).

The inner city of Pretoria is a catch basin for many transnational migrants, especially from other African countries. The term 'transnational' is used in this article not without noting that it is contested by various scholars. Peggy Levitt and Nadya Jaworsky in their article 'Transnational migration studies: Past developments and future trends' (2007) explore the tensions and issues that are raised with this term. They argue that transnational migration and contemporary 'globalisation' must be approached 'as a stage in ongoing historical processes' (p. 146). I will not explore the various arguments in this article. The term 'transnational' is used to describe people who migrate over boarders, to other countries other than their birth country. 'Transnational migrants are individuals who live aspects of their social, economic and political lives in at least two settings' and that they are at the same time established in the host country and continue to participate socially, economically, and politically in their countries of origin (Levitt 2003:850).

The statistics of the 2011 population census (Statistics South Africa 2011) pointed out that the proportion of external migration present in the City of Tshwane is relatively low (89.9\% of the population of the City of Tshwane are born in South Africa). This can be argued that the reason the official statistics are so low, is because 'that there tends to be little quantitative information about migrants, as they often escape counting in surveys and censuses' (De Haan 2000:11).
As mentioned, with the rural-urban and transnational migration, a cultural diverse cosmopolitan character develops in the inner city. One of the focus groups described this development as positive; it contributes to a more inclusive society, and a more diverse and religiously rich church. But on the other side, it became evident that foreign nationals experience victimisation in the city created by language barriers and discrimination in terms of language.

During a world cafe, churches in the inner city noted that the languages are more diverse in the city than in the townships and therefore people flock to the city to attend the churches rather that in the townships. In the townships, the languages that are used tend to be the vernacular language that excludes a lot of people. The city centre uses various languages for communication with English being the predominant language. It is therefore much easier for foreign nationals to integrate into the inner city than in the townships.

The focus groups in the inner city of Pretoria mentioned that their congregations have experienced urban-suburban migration. During the early 1990s, cities that were previously exclusive, all white cities, became home to people who were previously excluded. Pretoria experienced significant demographic change, where majority of the white people moved from the inner city to suburban areas (Donaldson 2005:57). Today we still find that the majority of white people do not live in the inner city of Pretoria or in Mamelodi, but in the suburban areas. This was noted by the focus groups that the inner city has a noticeable lack of white people. In Mamelodi there was no mention of white people in the area or the concern about a lack of white people. One of the focus groups that has a large number of white congregants noted that white people moved from the inner city because of their perception that the city has a high crime rate.

The various focus groups also noted that there is a generational migration, that is, older people moving out of the city centre and younger people moving into the city centre. This leads to the fact that the age demographics of the city is relatively young.

During a follow-up world cafe in the inner city and in Mamelodi East, the notion of migration was interrogated. It became clear that the churches did not consciously reflect on migration in their congregations, neither did they respond to migration. What the churches reflected on is that people 'migrate' in terms of church attendance. They travel on a weekly basis from where they stay to worship at a particular church. I will further explore this in the section of the identity of the churches.

\section{Describing causes of migration}

Migration and the causes of migration are complex issues. It is 'multilevel in nature, difficult to determine, and not easily generalisable' (Kok \& Collinson 2006:10). During the focus groups, it was clear what the churches perceived as the causes of migration (temporary and permanent) was the following: 
seeking economic opportunities, seeking education, escaping situations of abuse or conflict, perceptions of crime in a particular area and migrating into or out of an area because of age (Collinson, Kok \& Ganenne 2006; Kok \& Collinson 2006; Levitt \& Jaworsky 2007; Nshimbi \& Fioramonti 2014:52; World Bank 2016).

The reasons why people migrate can be described within three categories: social, political and economic. The three categories are not in isolation from one another. They overlap and are sometimes difficult to distinguish.

People migrate (either internally or externally) because of 'their expectations for the current area become lower than those in respect of an alternative place of residence'. How they migrate and where they migrate to are 'influenced by the information received about the alternative place of abode from relatives and friends living there' (Kok \& Collinson 2006:1314). It becomes clear that social networks form an important role in migrations. This becomes especially true for the integration in the host country or host city. The social networks help migrants to 'cut across class and spatial boundaries' and 'circumvent structural disadvantages' (Levitt \& Jaworsky 2007:135). As Morris (1996:30) notes that in the black urban American church, the church played the facilitation role of the social networks. People migrate 'if they have reason to believe that these networks at the possible destination will provide assistance and support during and after the move' (Kok \& Collinson 2006:13-14). Transnational migrants tend to maintain their social networks and support structures in their countries of origin if they should need to return (Kok \& Collinson 2006:13-14). All of the above mentioned is made easier through improved technological access such as telephones and the internet (World Bank 2016:vii).

Research about generational migration shows that 'younger, unmarried adults' are 'more inclined to migrate', as well as people who are more of risk-takers (Kok \& Collinson 2006:1314). This can be ascribed to the seeking of furthering their education. The focus groups noted that elderly people choose to live in suburban areas than in the inner city, and therefore they migrate out of the city.

Economic migration forms a large part of the reasons why people migrate. It is suggested that decisions regarding migration is not taken by an individual in isolation, 'but rather by families or household'. This is done to diversify the income of a family and the allocation of household resources (Kok et al. 2003:14). Decisions to migrate can be influenced by high poverty in their country or area of origin. Through the social networks, they receive information from people who already migrated to other countries or cities. The high level of poverty in their area and the prospects of employment or to attain a better life play a role in the decision-making process to migrate. People are also drawn to migrate to metropolitan areas because of a labour or skill shortage (World Bank 2016:vii).

One of the churches uses three distinct languages: English, German and Afrikaans. The German and Afrikaans members are predominantly white people. The other members are predominantly black Africans. Their responses to economic migration differed notably. The white members lamented the fact that there is an increase in poverty, crime and unemployment in the city. Many of the white members migrated to countries such as Germany to find employment opportunities. The predominantly black African counterpart of the congregation noted that people move to the inner city of Pretoria because of better employment opportunities and for the alleviation of poverty. Within this particular church, it is clear that the legacies of apartheid are still alive in terms of the lack of equal access.

The focus groups noted that there is a high number of internal and external migrants present in the city that are seeking employment or to escape their situation of poverty, abuse, violence or destruction from their places of origin. As mentioned, the churches reflected negatively on people who migrate for economic reasons, as they believe the migrants contribute to poverty, unemployment, decline in safety and the general decay of the neighbourhoods and city.

Migration is also caused by various political reasons. After 1994 and because the segregations laws no longer excluded certain people from certain areas, many black African people migrated to the city. Many external migrants that are present in the city leave their countries of origin because of political reasons. They are either escaping situations of violence or political instability. Most people who end up in metropolitan areas do not prefer to move to the metropolitan areas. They end up there because of the various reasons that have been described (Kok \& Collinson 2006:13-14).

\section{Describing the identity of the churches}

'Religion plays a critical role in identity construction, meaning making, and value formation' (Levitt 2003:851). How the churches self-identified influenced how they reflected on migration. There is a strong component about individual and group identity formation in research about religion and migration (Cadge \& Ecklund 2007:363).

Rural-urban and transnational migrants live with multiple identities, and religion is used to construct their identities in multiple ways (Cadge \& Ecklund 2007:364). Their social, economic and political lives are based in their host country or region, as well as their country or region of origin. Identity that is shaped by religion helps facilitate the integration of the migrants into the host city or country. Migrants also shape the religious identity of the local church (Cadge \& Ecklund 2007:370).

It became clear that the majority of commuter churches' conciseness and reflection differed vastly on their neighbourhood and responses to migration than local churches. Almost all the churches (both in Mamelodi and Pretoria Central) noted that migrants come to church to seek assistance when they have no family, support or social 
networks. They acknowledge the presence of migrants, but there are not clear responses to migration of the issues that migrants face.

During the second world cafe, the reflections about migrations was in terms of people travelling to attend church activities, members moving from one church to another or youth that move to other churches after confirmation.

The churches in Mamelodi indicated that their congregants are mostly South African and living close to the church, that is, a local church. During the second world cafe session in Mamelodi, it was mentioned that there are some churches that have congregants who travel from far places (such as Hammanskraal, Soshanguve and Atteridgeville) to attend church activities. In the inner city the majority of the churches' congregants do not live in close proximity of the church and travel to the city for church activities. They are considered as commuter churches.

One of the churches in Salvokop that participated in the focus groups is considered a local church as the majority of their members walk to church. They were much more in touch with their neighbourhood and the issues that the area faces. They reflected negatively on migration and associated migration with social decay and with higher levels of poverty.

The churches that were predominantly commuter churches, reflected more positively on migration. It was clear that the commuter churches are less in touch with the immediate neighbourhood of the church than the local churches. The commuter churches' reflections were around the issues of lack of space and safe parking. There was a clear distinction between the members of the church and the surrounding neighbourhood.

Many of the focus groups surfaced the issue of home versus temporary churches among migrants (internal and external). The focus groups described the idea of a home church as a place where people attend and are confirmed as members; partake in the church activities; and with a strong emphasis on financial contributions.

The idea of a temporary church was described by the focus groups where people attend a certain church in the city but consider their church from their place of origin as their home church. Their first loyalty is with their home church and not with the local congregation. It was described that they only 'consume church' with the local congregation. It was suggested that people who only 'consume church' do not invest themselves in the particular neighbourhood and do not participate in the life of the city, because it is not their home. They work and live in the city but financially sustain family members in other areas. This was stated in terms of rural-urban migration as well as transnational migration.

This temporary migration patterns are described as temporary circular migration and are found all over Southern
Africa. Kok and Collinson (2006) describe it as where a household that is:

based in a rural or peri-urban setting can have one or more linked temporary migrants remitting money back from another, usually urban, place of work. A migration is circular when the usual place of residence (de jure) remains in the rural or peri-urban setting, but a person migrates usually for employment or educational purposes, and stays connected to the 'sending' household through communication, regular return visits and with a high likelihood of cash or non-monetary remittance. (pp. 4-5)

According to the World Bank, ' $[m]$ igrants are now sending earnings back to their families in developing countries at levels above US $\$ 441$ billion, a figure three times the volume of official aid flows'. This inflow of cash 'lead to increased investments in health, education, and small businesses in various communities' (World Bank 2016:vii).

\section{Conclusion}

It is clear that the churches in Pretoria central as well as in Mamelodi East do not reflect on migration and how to respond to the issues of migrants. The churches are aware of migrants, whether they are internal migrants or external foreign national migrants. Even the churches that are led by foreign nationals in Pretoria Central do not respond to migrants.

Urbanisation is on the rise worldwide. Cities and neighbourhoods are going to become increasingly more cosmopolitan in nature. Churches continue to play an important role in the social fabric of South Africa, and therefore they have a responsibility to respond to migration. There is a strong link between religion and migration; churches are uniquely situated to respond to migration by facilitating the establishment of social networks that help with the integration process to circumvent structural disadvantages. At the current moment, the temporary local host churches juxtaposition themselves to the home churches. This breaks down the facilitation of integration of migrants. Churches must understand that migration is a continuous process, back and forth, and focus on building networks with the rural and townships churches to help facilitate healthier migration.

As it was mentioned in the focus groups that foreign national migrants are discriminated against, churches can participate to break the stereotypes about foreign migrants in South Africa. Deliberate conscientisation is needed for congregants to contribute to dispel the myth that migration causes poverty, unemployment and the decay of public safety and to integrate migrants into society. Churches play an important role to partake in the creation of a healthy and vibrant society that is seeking God's shalom for the city.

\section{Acknowledgements Competing interests}

The author declares that he has no financial or personal relationships which may have inappropriately influenced him in writing this article. 


\section{References}

Adepoju, A., 2016, Migration dynamics, refugees and internally displaced persons in Africa, United Nations Academic Impact, viewed 10 June 2017, from https:// academicimpact.un.org/content/migration-dynamics-refugees-and-internallydisplaced-persons-africa

Bakewell, O., 2008, “Keeping them in their place": The ambivalent relationship between development and migration in Africa', Third World Quarterly 29, 1341-1358. https://doi.org/10.1080/01436590802386492

Cadge, W. \& Ecklund, H.E., 2007, 'Immigration and religion', Annual Review of Sociology 33, 359-379. https://doi.org/10.1146/annurev.soc.33.040406. 131707

Chabalala, J., 2017, 'Anti-immigrant march expected in Pretoria', News24, viewed 15 June 2017, from http://www.news24.com/SouthAfrica/News/anti-immigrant15 June 2017, from http://www.news $24 . c 170224$
march-expected-in-pretoria-201702

Collinson, M., Kok, P. \& Ganenne, M., 2006, Migration and changing settlement patterns: Multilevel data for policy. Report 03-04-01, Human Sciences Research Council), Statistics South Africa, Pretoria.

De Haan, A., 2000, Migrants, livelihoods, and rights: The relevance of migration in development policies, Social Development Working Paper 4 38, viewed n.d., from https://www.researchgate.net/profile/Arjan_Haan/publication/252836337 Migrants_Livelihoods_and_Rights_The _Relevance_of_Migration_in Development_Policies/links/54ec5e0d0_cf27fbfd76f9e4e/M̄igrants-Livelihoodsand-Rights-The-Relevance-of-Migration-in-Development-Policies.pdf

Donaldson, R., 2005, 'Contesting the proposed rapid rail link in Gauteng', Urban Forum 16, 55-62. https://doi.org/10.1007/s12132-005-0016-x

Gauteng City-Region Observatory, n.d., The Gauteng City-Region, viewed 15 June 2017, from http://www.gcro.ac.za/about/the-gauteng-city-region/

Groody, D.G., 2013, 'The Church on the move: Mission in an age of migration', Mission Studies 30, 27-42. https://doi.org/10.1163/15733831-12341256

Groody, D., 2015, 'Migrants and refugees: Christian faith and the globalization of solidarity', The International Review of Mission 104, 314-323. https://doi.org/ solidarity', The Inter
10.1111 /irom. 12105

Jennings, W.J., 2010, The Christian imagination: Theology and the origins of race, Yale University Press, New Haven, London.

Kok, P. \& Collinson, M., 2006, Migration and urbanisation in South Africa, Statistics South Africa, Pretoria.

Kok, P., O'Donovan, M., Bouare, O. \&Van Zyl, J., 2003, Post-apartheid patterns of internal migration in South Africa, HSRC Publishers, Cape Town.

Levitt, P., 2003, “'You know, Abraham was really the first immigrant": Religion and transnational migration', International Migration Review 37, 847-873. https://doi. org/10.2307/30037759
Levitt, P. \& Jaworsky, B.N., 2007, 'Transnational migration studies: Past developments and future trends', Annual Review of Sociology 33, 129-156. https://doi. and future trends', Annual Review of Socio
org/10.1146/annurev.soc.33.040406.131816

Morris, A., 1996, 'The Black Church in the Civil Rights Movement: The SCLC as the decentralized, radical arm of the Black Church', in C. Smith (ed.), Disruptive religion: The force of faith in social movement activism, Routledge, New York.

News24 Reporters, 2017, 'WRAP: Pretoria brought to a standstill during antiimmigrant march', News24, viewed 15 June 2017, from http://www.news24.com/ SouthAfrica/News/wrap-pretoria-brought-to-a-standstill-during-anti-immigrantmarch-20170224

Nshimbi, C.C. \& Fioramonti, L., 2014, 'The will to integrate: South Africa's responses to regional migration from the SADC region', African Development Review 26, 52-63. https://doi.org/10.1111/1467-8268.12092

Reed, H.E., 2013, 'Moving across boundaries: Migration in South Africa, 1950-2000', Demography 50, 71-95. https://doi.org/10.1007/s13524-012-0140-x

Saunders, D., 2010, Arrival city: How the largest migration in history is reshaping our world, Random House, London.

Statistics South Africa, 2010, Statistics South Africa. Mid-year population estimates. (Report P03022010), Statistics South Africa, Pretoria.

Statistics South Africa, 2011, Census 2011, Statistics South Africa, Pretoria.

Statistics South Africa, 2016, Community Survey, Statistics South Africa, Pretoria.

Swilling, M., Humphries, R. \& Shubane, K. (eds.), 1991, Apartheid city in transition, Oxford University Press, Cape Town.

Terreblanche, S., 2014, Western empires, Penguin Books, Johannesburg.

Terreblanche, S.J., 2002, A history of inequality in South Africa, 1652-2002, University of Natal, Pietermaritzburg.

United Nations, Department of Economic and Social Affairs, Population Division, 2016, International Migration Report 2015: Highlights (ST/ESA/SER.A/375), United Nations, New York.

Van Eck, E., Renkin, W. \& Ntakirutimana, E., 2016, 'The parable of the Feast (Lk 14:16b-23): Breaking down boundaries and discerning a theological-spatial justice agenda', HTS Teologiese Studies/Theological Studies 72, 1-8. https://doi. org/10.4102/hts.v72i1.3512

Vellem, V.S., 2014, 'The task of urban black public theology', HTS Teologiese Studies/ Theological Studies 70, 1-6. https://doi.org/10.4102/hts.v70i3.2728

Vosloo, R., 1947, 'From a farm road to a public highway : The Dutch Reformed Church and its changing views regarding the city and urbanisation in the first half of the 20th century', Studia Historiae Ecclesiasticae, 39, 19-32.

World Bank, 2016, Migration and remittances factbook 2016, 3rd edn., World Bank, Washington, DC.

Wright, C.J.H., 2010, The mission of God's people abiblical theology of the church's mission, Zondervan, Grand Rapids, MI. 